\title{
FLORA AND VEGETATION FEATURES OF THE STOW «CHALK SLOPES TO THE PROVAL RIVER» (ULYANOVSK REGION)
}

(C) 2019

Saksonov Sergey Vladimirovich, doctor of biological sciences, professor, director Institute of Ecology of the Volga River Basin of the Russian Academy of Sciences branch of the Samara Federal Research Center of the Russian Academy of Sciences (Togliatti, Samara Region, Russian Federation)

Novikova Lyubov Aleksandrovna, doctor of biological sciences, professor of General Biology and Chemistry Department Penza State University (Penza, Russian Federation)

Vasjukov Vladimir Mikhailovich, candidate of biological sciences, researcher of Phytodiversity Problems Laboratory

Institute of Ecology of the Volga River Basin of the Russian Academy of Sciences branch of the Samara Federal Research Center of the Russian Academy of Sciences (Togliatti, Samara Region, Russian Federation)

Rakov Nikolay Sergeevich, candidate of biological sciences

Togliatti branch of Russian Botanical Society (Ulyanovsk, Russian Federation)

Senator Stepan Aleksandrovich, candidate of biological sciences,

senior researcher of Phytodiversity Problems Laboratory; associate professor of Design Center

Institute of Ecology of the Volga River Basin of the Russian Academy of Sciences - branch of the Samara Federal Research Center of the Russian Academy of Sciences (Togliatti, Samara Region, Russian Federation);

Togliatti State University (Togliatti, Samara Region, Russian Federation)

Silaeva Tatyana Borisovna, doctor of biological sciences,

professor of Botany, Physiology and Ecology of Plants Department

National Research Ogarev Mordovia State University (Saransk, Russian Federation)

Abstract. The paper contains the vegetation study results of the valuable botanical object «Chalk slopes to the Proval river». The stow is located in the vicinities of the village Beketovka (Veshkaymsky District of Ulyanovsk Region) and is proposed for inclusion in the regional network of protected areas. The data of floral and phytocenotic studies are presented. The flora of the stow «Chalk slopes to the Proval river» contains 287 species of vascular plants including 8 species listed in Red data book of the Russian Federation: Hedysarum gmelinii, Iris aphylla, Koeleria sclerophylla, Matthiola fragrans, Pinus cretacea [P. sylvestris var. cretacea], Stipa pennata, S. pulcherrima, Thymus dubjanskyi [Th. cimicinus auct. p. max. p.]. The regional rare and requiring protection plants are Adonanthe vernalis, Anemone sylvestris, Asperula exasperata, Aster alpinus, Betula krylovii, Bupleurum falcatum, Carex pediformis, Centaurea ruthenica, Crepis pannonica, Delphinium cuneatum, Galatella linosyris, Galium hexanarium, Gentiana cruciata, Gentianella amarella, Helianthemum canum, H. nummularium, Helictotrichon desertorum, Herminium monorchis, Jurinea ledebourii, Linum flavum, L. uralense, Onosma simplisissima s. str., O. volgensis, Otites baschkirorum, Parnassia palustris, Polygala cretacea, P. sibirica, Pulsatilla patens, Scabiosa isetensis, Schoenus ferrugineus. Calcephitic florocoenotic complex of the stow «Chalk slopes to the Proval river» (Ulyanovsk Region) is characterized by a mosaic of vegetation. Here, in a relatively small area, meadow, petrophytic and grass-mixed steppes, forest edges communities are presented. The floristic composition of these communities is peculiar and characterized by the presence of a large number of rare species including relict and endemic elements. In addition, in the central part of the Volga Upland, only a small amount of erosion-chalk landscapes with a high degree of preservation is known. The studied stow is recommended for inclusion in the system of protected areas of the Ulyanovsk Region.

Keywords: flora; vascular plants; rare steppe communities; mosaic of vegetation; nature conservation; Red data book of the Russian Federation; Red data book of the Ulyanovsk Region; valuable object; perspective nature monument; Volga Upland; Ulyanovsk Region.

\section{ЭКОЛОГО-СУБСТРАТНАЯ ХАРАКТЕРИСТИКА ЛИХЕНОФЛОРЫ ГОСУДАРСТВЕННОГО ПРИРОДНОГО ЗАКАЗНИКА «ЗАВОЛЖСКИЙ» (ЧУВАШСКАЯ РЕСПУБЛИКА)}

(C) 2019

\author{
Синичкин Евгений Аркадьевич, научный сотрудник \\ Димитриев Александр Вениаминович, кандидат биологических наук, директор \\ Чебоксарский филиал Главного ботанического сада им. Н.В. Цииина РАН \\ (2. Чебоксары, Российская Федераиия)
}

Аннотаиия. В статье приводится эколого-субстратный анализ лишайников государственного природного заказника «Заволжский» Чувашской Республики. В указанном заказнике обнаружено 134 вида лишайников. 
Эколого-субстратный анализ показал, что лишайники произрастают на 20 субстратах: на коре Populus tremula, Tilia cordata, Quercus robur, Acer platanoides, Betula pubescens, Padus avium, Sorbus aucuparia, Frangula alnus, Salix cinerea, S. pentandra, Alnus glutinosa, на коре и ветках Pinus sylvestris, Picea abies, Abies sibirica, Betula pendula, на почве, на мертвом органическом субстрате, на антропогенных субстратах (на шифере, бетоне, резине колеса автомобиля). В результате исследований выявлено 6 основных и 4 промежуточных экологических групп лишайников: 1) эпифитные, растущие на коре деревьев и кустарников; 2) эпиксильные, обитающие на гниющей древесине; 3) эпигейные (напочвенные лишайники); 4) эпибриофитные, обитающие на мхах; 5) эпифито-эпиксильные, произрастающие на коре деревьев и мёртвом органическом субстрате; 6) эпиксильно-эпигейные, обитающие на мёртвом органическом субстрате и почве; 7) лишайники, произрастающие на коре деревьев и антропогенном субстрате; 8) эпифитно-эпигейные, произрастающие на коре деревьев и поверхности почвы; 9) эврисубстратные лишайники, обитающие на разных субстратах; 10) лишайники антропогенного субстрата. Наибольшее количество лишайников относятся к эпифитам $-61,2 \%$, к эпифито-эпиксилам $-16,5 \%$, к эпиксило-эпигеидам $-5,2 \%$, к эпигеидам $-4,5 \%$, к эпиксилам $-3,7 \%$, эпибриофитам $-2,3 \%$, эврисубстратным лишайникам $-0,7 \%$, эпифито-эпигеидам $-0,7 \%$. На антропогенном субстрате обнаружены 3 вида лишайников (2,3\%). Эпифитные лишайники обнаружены на 15 форофитах. Наибольшее количество таксонов обнаружено на коре Pinus sylvestris - 40 видов, на коре Populus tremula - 35 видов, на коре Betula pendula - 33 вида. 56 видов лишайников обнаружены только на одном форофите. Анализ приуроченности к форофиту показал, что наибольший уровень сходства видового состава лишайников обнаружено между Padus avium и Frangula alnus - 50\%, Pinus sylvestris и Picea abies - 49\%, Populus tremula и Sorbus aucuparia $-44 \%$, Tilia cordata и Acer platanoides $-41 \%$, Salix cinerea и S. pentandra - 37\%.

Ключевые слова: лишайники; государственный природный заказник «Заволжский»; особо охраняемая природная территория; эколого-субстратный анализ; экологические группы; субстратная приуроченность; форофиты; уровень сходства лишайников; Чувашское Заволжье; Чувашская Республика.

\section{Введение}

По природному районированию В.Г. Папченкова, А.В. Димитриева, территория Чувашского Заволжья относится к природному району Заволжье, который характеризуется южнотаежной растительностью [1]. На территории Заволжья Чувашской Республики в настоящее время расположена единственная и уникальная особо охраняемая природная территория регионального значения - государственный природный заказник «Заволжский» (далее - заказник), основанный в 2017 году [2; 3]. Заказник состоит из трех кластерных участков (бывших памятников природы): участок № 1 (озеро Светлое и прилегающие леса), участок № 2 (озера и леса вокруг Большого и Малого Лебединого, Изъяр), участок № 3 (озеро Астраханка) [4-7]. На территории заказника обнаружено 134 вида лишайников, из них 15 редких видов, предложенных в новое издание Красной книги Чувашской Республики [8].

Ранее нами был опубликован аннотированный список лишайников государственного природного заказника «Заволжский» и ряд статей по лихенофлоре Заволжья Чувашской Республики [9-12]. Данная статья является продолжением указанных работ и посвящена эколого-субстратной характеристике лишайников государственного природного заказника «Заволжский» Чувашской Республики.

Цель нашего исследования - изучение субстратной приуроченности лишайников на территории государственного природного заказника «Заволжский» Чувашской Республики.

\section{Материалы и методы исследований}

На основе полученных данных в результате лихенологических исследований в 2011-2019 гг. нами было установлено произрастание 134 видов лишайников на территории ГПЗ «Заволжский» Чувашской Республики [9]. В этой работе нами проведен эколого-субстратный анализ лишайников указанного заказника. Экологические группы лишайников по отношению к субстрату выделены на основе работ Н.С. Голубковой, Х.Х. Трасса, А.Н. Окснера [13; 14], с учетом последних исследований [15-23]. Отнесение конкретного вида к той или иной эколого- субстратной группе сделано на основе собственных исследований, так как известно, что один и тот же вид лишайника в разных частях своего ареала способен переходить на новый для него субстрат [24].

Названия форофитов дана по сводке П.Ф. Маевского «Флора средней полосы европейской части России» [25]. Для анализа уровня сходства лишайников между форофитами использовали индекс сходства Чекановского-Съеренсена [26].

\section{Результаты и их обсуждение}

По отношению к субстрату и другим условиям местообитания лишайники подразделяются на следующие экологические группы: эпифитные (развиваются на коре деревьев и кустарников), эпигейные (развиваются на поверхности почвы), эпиксильные (развиваются на мертвом органическом субстрате), эпилитные (развиваются на камнях), эпифильные (развиваются на хвое и листьях вечнозелёных растений), эпибриофитные (развиваются на мхах), эврисубстратные (произрастают на нескольких субстратах), лишайники антропогенного субстрата (произрастают на субстратах, созданным человеком) [1323]. В некоторых работах выделяются промежуточные эколого-субстратные группы для описания микроусловий произрастания лишайников [20;27].

В результате исследований нами выявлены 6 основных и 4 промежуточных экологических групп лишайников (эти группы приведены в \% от общего количества обнаруженных видов в заказнике): эпифиты - 82 вида $(61,2 \%)$, эпигеиды - 6 видов $(4,5 \%)$, эпиксилы - 5 видов $(3,7 \%)$, эпибриофиты - 3 вида $(2,3 \%)$, эврисубстратные лишайники - 1 вид $(0,7 \%)$, эпиксилыэпигеиды - 7 видов $(5,2 \%)$, эпифито-эпиксилы - 22 вида $(16,5 \%)$, эпифито-эпигеиды - 1 вид $(0,7 \%)$.

К эпигейным (почвенным) лишайникам относятся 6 видов (Cetraria islandica, Cladonia cervicornis, $\mathrm{Cl}$. stellaris, Cl. turgida, Cl. uncialis, Peltigera malacea). K эпибриофитам относятся представители рода Мусоbilimbia (Mycobilimbia epixanthoides, M. carneoalbida, M. tetramera), которые найдены в замшелой прикомлевой части Populus tremula. Лишайник Cladonia cenotea нами отнесен к группе эврисубстратных ли- 
шайников, так как обнаружен на почве, мертвом органическом субстрате, на стволе Betula pubescens и в прикомлевой части Pinus sylvestris.

На мертвом органическом субстрате нами обнаружено 5 видов лишайников (Cladonia ramulosa, Lecanora hagenii, Lecanora varia, Parmeliopsis ambigua, P. hyperopta), которые произрастали на гниющей (валеже) и обработанной древесине. Лишайник Lepraria incana был найден на откосе насыпи дороги и на коре Pinus sylvestris, Tilia cordata, Abies sibirica и отнесен к промежуточной экологической группе эпифито-эпигеиды.

К лишайникам антропогенного субстрата отнесено 3 вида (2,3\% от общего числа видов). Лишайники Acarospora moenium и Candelariella aurella произрастали на шифере и бетоне бывшего кордона. Bacidina delicata нами обнаружена на резине колеса автомобиля. Также нами выделена эколого-субстратная группа лишайников, произрастающих на коре деревьев и антропогенном субстрате - 4 вида или $2,9 \%$ от общего числа видов (Caloplaca holocarpa, Candelariella xanthostigma, Phaeophyscia nigricans, Physcia adscendens).

Большая часть выявленных лишайников относятся к эпифитам и были обнаружены на 15 форофитах: Pinus sylvestris, Picea abies, Abies sibirica, Populus tremula, Tilia cordata, Quercus robur, Acer platanoides, Betula pendula, B. pubescens, Padus avium, Sorbus aucuparia, Frangula alnus, Salix cinerea, S. pentandra, Alnus glutinosa.

Субстратная приуроченность лишайников на территории заказника приводится в таблице 1.

Нами обнаружено, что наибольшее количество эпифитных лишайников произрастают на коре Pinus sylvestris - 40 видов, на коре Populus tremula - 35 видов, на коре Betula pendula - 33 вида, на коре Salix cinerea - 19 видов. Наименьшее количество лишайников обнаружено на следующих форофитах: на коре Sorbus aисираria - 10 видов, на коре Abies sibirica 8 видов, на коре Quercus robur - 3 вида.

56 видов лишайников произрастают только на одном форофите, из них:

- на коре Populus tremula - 18 видов (Anaptychia ciliaris, Arthonia patellulata, Bacidia igniarii, B. rubella, Lecanora allophana, Lecidella euphorea, Melanelixia subargentifera, Mycobilimbia epixanthoides, M. carneoalbida, M. tetramera, Peltigera canina, P. polydactylon, P. praetextata, Pertusaria amara, Phaeophyscia ciliata, Pseudoschismatomma rufescens, Ramalina farinacea, Xanthomendoza ulophyllodes);

- на коре Pinus sylvestris - 11 видов (Cladonia botrytes, Cl. deformis, Cl. pleurota, Hypogymnia tubulosa, Imshaugia aleurites, Lecanora piniperda, Micarea misella, Parmeliopsis ambigua, Placynthiella icmalea, Pycnora praestabilis, Usnea dasopoga);

- на коре Betula pendula - 5 видов (Bryoria subcana, Buellia griseovirens, Physcia tribacia, Polycauliona polycarpa, Trapeliopsis flexuosa);

- на коре Tilia cordata - 5 видов (Acrocordia gemmata, Dimerella pineti, Flavoparmelia caperata, Lobaria pulmonaria, Ramalina pollinaria);

- на коре Salix cinerea - 4 вида (Bacidina chloroticula, Lecanora expallens, Rinodina pyrina, Usnea lapponica);

- на коре Salix pentandra - 4 вида (Bacidia arceutina, B. circumspecta, Catillaria nigroclavata, Eopyrenula leucoplaca);
- на коре Abies sibirica - 2 вида (Arthonia cinereoprunosa, Opegrapha vulgata);

- на коре Padus avium - 2 вида (Pertusaria coccodes, Melanelixia glabratula);

- на коре Acer platanoides - 2 вида (Arthonia exilis, Lecanora thysanophora);

- на коре Picea abies - 1 вид (Platismatia glauca);

- на коре Betula pubescens - 1 вид (Cladonia cornuta);

- на коре Alnus glutinosa - 1 вид (Caloplaca cerina).

47 видов лишайников обнаружены на 2-4 форофитах, 10 видов встречаются на 5-7 форофитах (Buellia disciformis, Evernia prunastri, E. mesomorpha, Hypogymnia physodes, Lecanora symmicta, Melanohalea olivacea, Phaeophyscia orbicularis, Physconia distorta, Scoliciosporum chlorococcum, Xanthoria parietina), 2 вида - на 8-15 форофитах (Physcia adscendens, Parmelia sulcata).

Необходимо отметить, что редкие виды лишайников произрастают на таких форофитах, как Рориlus tremula - 4 вида, Pinus sylvestris - 3 вида, Tilia cordata - 2 вида, Picea abies - 2 вида, Abies sibirica 1 вид, Betula pendula - 1 вид, Salix cinerea - 1 вид, Frangula alnus - 1 вид.

Анализ приуроченности лишайников к форофиту выявил, что уровень сходства составляет по всем форофитам всего лишь 9\% (рис. 1.). На дендрограмме можно выделить 5 основных групп по форофиту. Наибольший уровень сходства видового состава лишайников обнаружено между Padus avium и Frangula alnus - 50\%, Pinus sylvestris и Picea abies - 49\%, Populus tremula и Sorbus aucuparia - 44\%, Tilia cordata и Acer platanoides - 41\%, Salix cinerea и S. pentandra -37\%, Quercus robur и Alnus glutinosa - $20 \%$.

\section{Выводы}

Эколого-субстратный анализ лихенофлоры государственного природного заказника «Заволжский» выявил 6 основных и 4 промежуточных экологических групп лишайников: эпифиты (82 вида), эпигеиды (6 видов), эпиксилы (5 видов), эпибриофиты (3 вида), эврисубстратные лишайники (1 вид), лишайники антропогенного субстрата (3 вида), эпифито-эпиксилы (22 вида), эпиксилы-эпигеиды (7 видов), эпифито-эпигеиды (1 вид), эпифит-антропогенный субстрат (4 вида).

Эпифитные лишайники произрастают на 15 форофитах, при этом только на 1 форофите - 56 видов, на 2-4 форофитах - 47 видов, на 5-7 форофитах 10 видов, на 8-15 форофитах - 2 вида. Наибольшее количество эпифитных лишайников произрастают на коре Pinus sylvestris - 40 видов, на коре Populus tremula - 35 видов, на коре Betula pendula - 33 вида, на коре Salix cinerea - 19 видов.

Анализ приуроченности лишайников к форофиту выявил 5 основных групп. Наибольший уровень сходства видового состава лишайников обнаружено между Padus avium и Frangula alnus - 50\%, Pinus sylvestris и Picea abies - 49\%, Populus tremula и Sorbus aucuparia - 44\%, Tilia cordata и Acer platanoides $41 \%$, Salix cinerea и S. pentandra - 37\%, Quercus robur и Alnus glutinosa - 20\%.

Редкие виды лишайников произрастают на 8 форофитах (Populus tremula, Pinus sylvestris, Tilia cordata, Picea abies, Abies sibirica, Betula pendula, Salix cinerea, Frangula alnus). 
Синичкин Е.А., Димитриев А.В.

Таблица 1 - Распределение лишайников по субстратам в государственном природном заказнике «Заволжский» Чувашской Республики

\begin{tabular}{|c|c|c|c|c|c|c|c|c|c|c|c|c|c|c|c|c|c|c|c|c|}
\hline Виды лишайников & 1 & 2 & 3 & 4 & 5 & 6 & 7 & 8 & 9 & 10 & 11 & 12 & 13 & 14 & 15 & 16 & 17 & 18 & 19 & 20 \\
\hline 1Acarospora moenium (Vain.) Räsänen & & & & & & & & & & & & & & & & & & + & + & \\
\hline 2 Acrocordia gemmata (Ach.) A. Massal. & & & & & & & & & + & & & & & & & & & & & \\
\hline 3 Amandinea punctata $_{\text {(Hoffm.) Coppins et Scheid. }}$ & & & & + & & & + & & & & & + & & & & & + & & & \\
\hline 4Anaptychia ciliaris (L.) Körb. & & & & & & + & & & & & & & & & & & & & & \\
\hline 5Arthonia cinereoprunosa Schaer. & & & + & & & & & & & & & & & & & & & & & \\
\hline 6Arthonia exilis (Flörke) Anzi & & & & & & & & & & & + & & & & & & & & & \\
\hline 7 Arthonia patellulata Nyl. & & & & & & + & & & & & & & & & & & & & & \\
\hline 8 Arthonia radiata (Pers.) Ach. & & & & & & & & & + & & + & & & & & & & & & \\
\hline 9 Bacidia arceutina (Ach.) Arnold & & & & & & & & & & & & & & + & & & & & & \\
\hline${ }_{10} \begin{array}{l}\text { Bacidia circumspecta } \\
\text { (Nyl. ex Vain.) Malme }\end{array}$ & & & & & & & & & & & & & & + & & & & & & \\
\hline 11 Bacidia igniarii (Nyl.) Oxner & & & & & & + & & & & & & & & & & & & & & \\
\hline 12 Bacidia rubella (Hoffm.) A. Massal. & & & & & & + & & & & & & & & & & & & & & \\
\hline $13 \mid \begin{array}{l}\text { Bacidina chloroticula } \\
\text { (Nyl.) Vězda et Poelt }\end{array}$ & & & & & & & & & & & & & + & & & & & & & \\
\hline 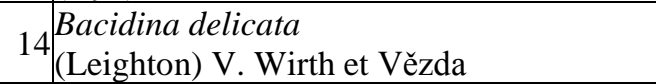 & & & & & & & & & & & & & & & & & & & & + \\
\hline $15 \begin{array}{l}\text { Bryoria implexa } \\
\text { (Hoffm.) Brodo et D. Hawksw. }\end{array}$ & + & & & + & & & & & & & & & & & & & & & & \\
\hline $16 \begin{array}{l}\text { Bryoria nadvornikiana } \\
\text { (Gyeln.) Brodo et D. Hawksw. }\end{array}$ & + & + & & & & & & & & & & & & & & & & & & \\
\hline $17 \begin{array}{l}\text { Bryoria subcana } \\
\text { (Nyl. ex Stizenb.) Brodo et D. Hawksw. }\end{array}$ & & & & + & & & & & & & & & & & & & & & & \\
\hline 18 Buellia disciformis (Fr.) Mudd & & & & + & & + & & + & + & & + & & & & & & & & & \\
\hline $19 \begin{array}{l}\text { Buellia griseovirens } \\
\text { (Turher et Borrer ex Sm.) Almb. }\end{array}$ & & & & + & & & & & & & & & & & & & & & & \\
\hline 20 Buellia schaereri De Not. & + & & & & & & & & & & & & + & & & & + & & & \\
\hline 21 Caloplaca cerina (Ehrh. ex Hedw.) Th. Fr. & & & & & & & & & & & & & & & + & & & & & \\
\hline $22 \begin{array}{l}\text { Caloplaca holocarpa } \\
\text { (Hoffm. ex Ach.) A.E. Wade }\end{array}$ & & & & + & & & & & & & & & + & & + & & & & + & \\
\hline $23 \begin{array}{l}\text { Caloplaca obscurella } \\
\text { (J. Lachm. et Körb.) Th. Fr. }\end{array}$ & & & & & & & & & & & & & + & + & + & & & & & \\
\hline 24 Candelariella aurella (Hoffm.) Zahlbr. & & & & & & & & & & & & & & & & & & + & + & \\
\hline $25 \begin{array}{l}\text { Candelariella vitellina } \\
\text { (Hoffm.) Müll. Arg. }\end{array}$ & & & & & & & & & & & & & + & + & + & & & & & \\
\hline 26 Candelariella xanthostigma (Ach.) Lettau & & & & + & & & & & & & & & + & & & & & & & + \\
\hline 27 Catillaria nigroclavata (Nyl.) Schuler & & & & & & & & & & & & & & + & & & & & & \\
\hline 28 Cetraria islandica (L.) Ach. & & & & & & & & & & & & & & & & + & & & & \\
\hline $\begin{array}{l}29 \begin{array}{l}\text { Chaenotheca chrysocephala } \\
\text { (Turner ex Ach.) Th. Fr. }\end{array} \\
\end{array}$ & + & + & & & & & & & & & & & & & & & & & & \\
\hline $30 \begin{array}{l}\text { Chaenotheca ferruginea } \\
\text { (Turner ex Sm.) Mig. }\end{array}$ & + & + & + & & + & & & & & & & & & & & & & & & \\
\hline 31 Chaenotheca furfuracea (L.) Tibell & + & + & & & + & & & & & & & & & & & & & & & \\
\hline \begin{tabular}{l|l}
32 Chaenotheca stemonea (Ach.) Müll. Arg. \\
\end{tabular} & + & + & & & & & & & & & & & & & & & & & & \\
\hline 33 Chaenotheca trichialis (Ach.) Th. Fr. & + & + & & & & & & & & & & & & & & & & & & \\
\hline 34 Cladonia arbuscula (Wall.) Flot. & & & & & & & & & & & & & & & & + & + & & & \\
\hline 35 Cladonia botrytes (K.G. Hagen) Willd. & + & & & & & & & & & & & & & & & & + & & & \\
\hline 36 Cladonia cariosa (Ach.) Spreng. & & & & & & & & & & & & & & & & + & + & & & \\
\hline 37 Cladonia cenotea (Ach.) Schaer. & + & & & & + & & & & & & & & & & & & + & & & \\
\hline 38 Cladonia cervicornis (Ach.) Flot. & & & & & & & & & & & & & & & & + & & & & \\
\hline \begin{tabular}{l|l}
39 & $\begin{array}{l}\text { Cladonia chlorophaea } \\
\text { (Flörke ex Sommerf.) Spreng. }\end{array}$
\end{tabular} & + & & & + & & + & & & & & & & & & & & + & & & \\
\hline 40 Cladonia coniocraea (Flörke) Spreng. & + & & & + & + & + & & & & & & & & & & & + & & & \\
\hline 41 Cladonia cornuta (L.) Hoffm. & & & & & + & & & & & & & & & & & + & + & & & \\
\hline \begin{tabular}{l|l}
42 Cladonia crispata (Ach.) Flot. \\
\end{tabular} & & & & & & & & & & & & & & & & + & + & & & \\
\hline 43 Cladonia deformis (L.) Hoffm. & + & & & & & & & & & & & & & & & & + & & & \\
\hline 44Cladonia digitata (L.) Hoffm. & + & & & & + & & & & & & & & & & & & + & & & \\
\hline
\end{tabular}


Синичкин Е.А., Димитриев А.В.

Эколого-субстратная характеристика лихенофлоры государственного природного заказника..

Обизая биология

\begin{tabular}{|c|c|c|c|c|c|c|c|c|c|c|c|c|c|c|c|c|c|c|c|c|c|}
\hline № & Виды лишайников & 1 & 2 & 3 & 4 & 5 & 6 & 7 & 8 & 9 & 10 & 11 & 12 & 13 & 14 & 15 & 16 & 17 & 18 & 19 & 20 \\
\hline & Cladonia fimbriata (L.) Fr. & + & & & & + & & & & & & & & & & & & + & & & \\
\hline & Cladonia gracilis (L.) Willd. & & & & & & & & & & & & & & & & + & + & & & \\
\hline & Cladonia macilenta Hoffm. & + & & & & + & & & & & & & & & & & & + & & & \\
\hline & Cladonia mitis Sandst. & & & & & & & & & & & & & & & & + & + & & & \\
\hline & Cladonia pleurota (Flörke) Schar. & + & & & & & & & & & & & & & & & & + & & & \\
\hline & Cladonia ramulosa (With.) J.R. Laundon & & & & & & & & & & & & & & & & & + & & & \\
\hline & $\begin{array}{l}\text { Cladonia rangiferina } \\
\text { (L.) Weber ex F.H. Wigg. }\end{array}$ & & & & & & & & & & & & & & & & + & + & & & \\
\hline & Cladonia stellaris (Opiz) Pouzar et Vězda & & & & & & & & & & & & & & & & + & & & & \\
\hline & Cladonia turgida Hoffm. & & & & & & & & & & & & & & & & + & & & & \\
\hline & $\begin{array}{l}\text { Cladonia uncialis } \\
\text { (L.) Weber ex F.H. Wigg. }\end{array}$ & & & & & & & & & & & & & & & & + & & & & \\
\hline & Dimerella pineti (Schrad. ex Ach.) Vězda & & & & & & & & & + & & & & & & & & & & & \\
\hline & $\begin{array}{l}\text { Eopyrenula leucoplaca } \\
\text { (Wallr.) R.C. Harris }\end{array}$ & & & & & & & & & & & & & & + & & & & & & \\
\hline & Evernia mesomorpha Nyl. & + & + & & + & + & & & + & & & & & & & + & & + & & & \\
\hline & Evernia prunastri (L.) Ach. & + & & & + & & & & & + & + & & & & + & + & & & & & \\
\hline & Flavoparmelia caperata (L.) Hale & & & & & & & & & + & & & & & & & & & & & \\
\hline & Graphis scripta (L.) Ach. & & & & & & & & & + & & + & & & & & & & & & \\
\hline & $\begin{array}{l}\text { Gyalecta fagicola } \\
\text { (Hepp ex Arnold) Kremp. }\end{array}$ & & & & & & & & & + & & & + & & & & & & & & \\
\hline & Hypocenomyce scalaris (Ach.) M. Choisy & + & & & + & + & & & & & & & & & & & & + & & & \\
\hline 63 & Hypogymnia tubulosa (Schaer.) Hav. & + & & & & & & & & & & & & & & & & & & & \\
\hline 64 & Hypogymnia physodes (L.) Nyl. & + & + & + & + & & & + & + & & + & & & & & & & + & & & \\
\hline 65 & Imshaugia aleurites (Ach.) S.L.F. Meyer & + & & & & & & & & & & & & & & & & & & & \\
\hline & Lecania cyrtella (Ach.) Th. Fr. & & & & & & + & & & & & + & + & + & & & & & & & \\
\hline & $\begin{array}{l}\text { Lecania naegelii } \\
\text { (Hepp) Diederich et van den Boom }\end{array}$ & & & & & & + & & & & & & + & + & & & & & & & \\
\hline & Lecanora allophana $\mathrm{Nyl}$ & & & & & & + & & & & & & & & & & & & & & \\
\hline & Lecanora conizaeoides Nyl. ex Cromb. & + & & + & + & & + & & & & & & & & & & & & & & \\
\hline & Lecanora expallens Ach. & & & & & & & & & & & & & + & & & & & & & \\
\hline & Lecanora hagenii (Ach.) Ach. & & & & & & & & & & & & & & & & & + & & & \\
\hline 72 & Lecanora piniperda Körb. & + & & & & & & & & & & & & & & & & & & & \\
\hline 73 & Lecanora populicola (DC) Dudy & & & & + & & & & & & & & & & & + & & & & & \\
\hline & Lecanora pulicaris (Pers.) Ach. & & & & + & & & & + & & & + & & & & & & + & & & \\
\hline & Lecanora symmicta (Ach.) Ach. & & & & & & & + & + & + & & + & & + & + & & & + & & & \\
\hline & Lecanora thysanophora R.C. Harris & & & & & & & & & & & + & & & & & & & & & \\
\hline & Lecanora varia (Hoffm.) Ach. & & & & & & & & & & & & & & & & & + & & & \\
\hline & $\begin{array}{l}\text { Lecidella euphoria } \\
\text { (Flörke) Hertel in Hawskw. }\end{array}$ & & & & & & + & & & & & & & & & & & & & & \\
\hline & Lepraria incana (L.) Ach. & + & & + & & & + & & & + & & & & & & + & & & & & \\
\hline & Lobaria pulmonaria (L.) Hoffm. & & & & & & & & & + & & & & & & & & & & & \\
\hline & $\begin{array}{l}\text { Melanelixia glabratula } \\
\text { (Lamy) Sandler \& Arup }\end{array}$ & & & & & & & + & & & & & & & & & & & & & \\
\hline & $\begin{array}{l}\text { Melanelixia subargentifera } \\
\text { (Nyl.) O. Blanco et al. }\end{array}$ & & & & & & + & & & & & & & & & & & & & & \\
\hline & $\begin{array}{l}\text { Melanelixia subaurifera } \\
\text { (Nyl.) O. Blanco et al. }\end{array}$ & & & & & & & + & + & & & & & & & & & & & & \\
\hline & Melanohalea olivacea (L.) O. Blanco et al. & + & & & + & & & + & + & + & & + & & & & & & & & & \\
\hline & $\begin{array}{l}\text { Melanohalea septentrionalis } \\
\text { (Lynge) O. Blanco et al. }\end{array}$ & & & & & & & + & + & & & & & + & & & & & & & \\
\hline & Micarea misella (Nyl.) Hedl. & + & & & & & & & & & & & & & & & & & & & \\
\hline & $\begin{array}{l}\text { Mycobilimbia epixanthoides (Nyl.) Vitik., } \\
\text { Ahti, Kuusinen, Lommi et T. Ulvinen }\end{array}$ & & & & & & + & & & & & & & & & & & & & & \\
\hline & $\begin{array}{l}\text { Mycobilimbia carneoalbida } \\
\text { (Mull. Arg.) Printzen }\end{array}$ & & & & & & + & & & & & & & & & & & & & & \\
\hline & $\begin{array}{l}\text { Mycobilimbia tetramera } \\
\text { (De Not.) Vitik., Ahti, Kuusinen, Lommi } \\
\text { et T. Ulvinen ex Hafellner et Türk }\end{array}$ & & & & & & + & & & & & & & & & & & & & & \\
\hline 90 & Opegrapha vulgata Ach. & & & + & & & & & & & & & & & & & & & & & \\
\hline 91 & Parmelia sulcata Taylor & + & + & & + & & + & + & + & & + & & + & & & & & + & & & \\
\hline
\end{tabular}


Синичкин Е.А., Димитриев А.В.

\begin{tabular}{|c|c|c|c|c|c|c|c|c|c|c|c|c|c|c|c|c|c|c|c|c|}
\hline Виды лишайников & 1 & 2 & $3 \mid$ & 4 & 5 & 6 & 7 & 8 & 9 & 10 & 11 & 12 & 13 & 14 & 15 & 16 & 17 & 18 & 19 & 20 \\
\hline 92 Parmeliopsis ambigua (Wulfen) Nyl. & + & & & & & & & & & & & & & & & & + & & & \\
\hline 93 Parmeliopsis hyperopta (Ach.) Arnold. & & & & & & & & & & & & & & & & & + & & & \\
\hline 94 Peltigera canina $($ L.) Willd. & & & & & & + & & & & & & & & & & & & & & \\
\hline 95 Peltigera malacea (Ach.) Funck & & & & & & & & & & & & & & & & + & & & & \\
\hline 96 Peltigera polydactylon (Neck.) Hoffm. & & & & & & + & & & & & & & & & & & & & & \\
\hline 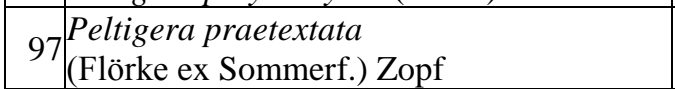 & & & & & & + & & & & & & & & & & & & & & \\
\hline 98 Pertusaria amara (Ach.) Nyl. & & & & & & + & & & & & & & & & & & & & & \\
\hline 99Pertusaria coccodes (Ach.) Nyl. & & & & & & & + & & & & & & & & & & & & & \\
\hline 100Phaeophyscia ciliata (Hoffm.) Moberg & & & & & & + & & & & & & & + & & & & & & & \\
\hline 101 Phaeophyscia nigricans (Flörke) Moberg & & & & & & + & & & & & & + & & + & & & & + & + & \\
\hline 102Phaeophyscia orbicularis (Neck.) Moberg & & & & + & & + & & & & & & + & + & + & & & & & & \\
\hline 103 Phlyctis argena (Spreng.) Flot. & & & $+t+1$ & + & & & & & & & & + & & & & & & & & \\
\hline 104Physcia adscendens (Fr.) H. Olivier & & & & + & & + & + & + & + & & & + & + & + & & & & & & \\
\hline 105 Physcia aipolia (Ehrh. ex Humb.) Fürnr. & & & & & & + & & & & & & + & & + & & & & & & \\
\hline 106 Physcia stellaris (L.) Nyl. & & & & & & + & & & & & & + & & + & & & & & & \\
\hline $\begin{array}{l}{ }_{107} \\
\begin{array}{l}\text { Physcia tenella } \\
\text { (Scop.) DC. in Lam. et DC. }\end{array}\end{array}$ & & & & & & & & & & & & + & & + & & & & & & \\
\hline 108Physcia tribacia (Ach.) Nyl. & & & & + & & & & & & & & & & & & & & & & \\
\hline 109Physconia detersa (Nyl.) Poelt & & & & + & & + & & & & & & + & & & & & & & & \\
\hline 110Physconia distorta (With.) J.R. Laundon & & & & + & & + & + & & & & & + & & + & & & & & & \\
\hline 111 Physconia enteroxantha (Nyl.) Poelt & & & & + & & & & & & & & + & & & & & & & & \\
\hline $112 \begin{array}{l}\text { Placynthiella icmalea } \\
\text { (Ach.) Coppins et P. James }\end{array}$ & + & & & & & & & & & & & & & & & & + & & & \\
\hline $113 \begin{array}{l}\text { Platismatia glauca } \\
\text { (L.) W. Culb. et C. Culb. }\end{array}$ & & + & & & & & & & & & & & & & & & & & & \\
\hline \begin{tabular}{l|l}
114 & $\begin{array}{l}\text { Polycauliona polycarpa } \\
\text { (Hoffm.) Frödén, Arup, et Søchting }\end{array}$
\end{tabular} & & & & + & & & & & & & & & & & & & & & & \\
\hline 115Pseudevernia furfuracea $(\mathrm{L}$.$) Zopf$ & + & + & & + & & & & + & & & & & & & & & + & & & \\
\hline $\begin{array}{l}116 \text { Pseudoschismatomma rufescens } \\
\text { (Pers.) Ertz et Tehler }\end{array}$ & & & & & & + & & & & & & & & & & & & & & \\
\hline 117Psilolechia lucida (Ach.) M. Choisy & + & + & + & & & & & & & & & & & & & + & & & & \\
\hline 118 Pycnora praestabilis (Nyl.) Hafellner & + & & & & & & & & & & & & & & & & + & & & \\
\hline 119Pycnora sorophora (Vain.) Hafellner & + & + & & & & & & & & & & & & & & & + & & & \\
\hline 120Ramalina farinacea $($ L.) Ach. & & & & & & + & & & & & & & & & & & & & & \\
\hline 121 Ramalina pollinaria (Westr.) Ach. & & & & & & & & & + & & & & & & & & & & & \\
\hline 122 Rinodina pyrina (Ach.) Arnold & & & & & & & & & & & & & + & & & & & & & \\
\hline 123Rinodina sophodes (Ach.) A. Massal. & & & & & & & & & & & & & + & + & & & & & & \\
\hline $124 \begin{array}{l}\text { Scoliciosporum chlorococcum } \\
\text { (Graewe ex Stenh.) Vězda }\end{array}$ & & & & + & & & & + & & & + & & + & + & & & + & & & \\
\hline 125 Strigula stigmatella (Ach.) R.C. Harris & & & & & & & + & & & & & + & & & & & & & & \\
\hline $126 \begin{array}{l}\text { Trapeliopsis flexuosa } \\
\text { (Fr.) Coppins et P. James }\end{array}$ & & & & + & & & & & & & & & & & & & + & & & \\
\hline 127Tuckermannopsis sepincola (Ehrh.) Hale & + & & & + & & & & & & & & & & & & & & & & \\
\hline 128 Usnea dasopoga (Ach.) Nyl. & + & & & & & & & & & & & & & & & & & & & \\
\hline 129 Usnea hirta (L.) Weber ex F.H. Wigg. & + & + & & + & & & & + & & & & & & & & & & & & \\
\hline 130 Usnea lapponica Räs. & & & & & & & & & & & & & + & & & & & & & \\
\hline 131 Usnea subfloridana Stirt. & + & & & & & & & + & & & & & & & & & & & & \\
\hline $132 \begin{array}{l}\text { Vulpicida pinastri } \\
\text { (Scop.) J.-E. Mattsson et M.J. Lai }\end{array}$ & + & & & + & & + & & & & & & & & & & & + & & & \\
\hline $\begin{array}{l}133 \begin{array}{l}\text { Xanthomendoza ulophyllodes } \\
\text { (Räsänen) Søchting et al. }\end{array} \\
\end{array}$ & & & & & & + & & & & & & & & & & & & & & \\
\hline 134Xanthoria parietina (L.) Th. Fr. & & & & + & & + & + & & & & & + & + & & & & & & & \\
\hline Итого: & 40 & 14 & & $33 \mid 1$ & 10 & 35 & 13 & 14 & 14 & 3 & 10 & 17 & 19 & 17 & 8 & 14 & 36 & 3 & 4 & 2 \\
\hline
\end{tabular}

Примечание. Числами в верхней строке обозначен субстрат: 1 - кора Pinus sylvestris; 2 - кора Picea abies; 3 - кора Abies sibirica; 4 - кора Betula pendula; 5 - кора Betula pubescens; 6 - кора Populus tremula; 7 - кора Padus avium; 8 - кора Frangula alnus; 9 - кора Tilia cordata; 10 - кора Quercus robur; 11 - кора Acer platanoides; 12 - кора Sorbus aucuparia; 13 - кора Salix cinerea; 14 - кора Salix pentandra; 15 - кора Alnus glutinosa; 16 - почва; 17 - мертвый органический субстрат (гниющая и обработанная древесина); 18 - бетонный столб; 19 - шифер; 20 - резина колеса автомобиля. 


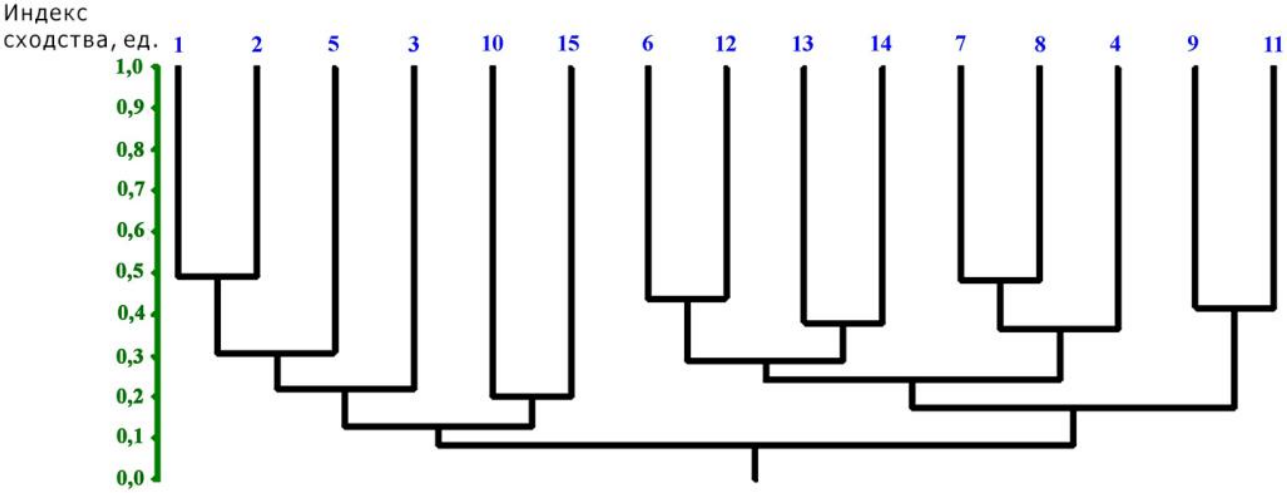

Рисунок 1 - Дендрограмма уровня сходства лишайников, произрастающих на форофитах: 1 - Pinus sylvestris, 2- Picea abies, 3-Abies sibirica; 4-Betula pendula; 5-Betula pubescens, 6- Populus tremula; 7- Padus avium; 8-Frangula alnus, 9- Tilia cordata; 10-Quercus robur, 11 - Acer platanoides, 12 - Sorbus aucuparia; 13 - Salix cinerea; 14- Salix pentandra; 15-Alnus glutinosa

\section{Список литературы:}

1. Папченков В.Г., Димитриев А.В. О природном районировании Чувашской Республики // Экологический вестник Чувашской Республики. Чебоксары, 1993. Вып. 2. С. 77-84.

2. О создании государственного природного заказника регионального значения «Заволжский»: Постановление Кабинета Министров Чувашской Республики от 24.08.2017 № 336 [Электронный ресурс] // Официальный интернет-портал правовой информации. - http://publication.pravo.gov.ru/Document/View/ 2100201708280018.

3. Материалы обследования флоры и фауны предлагаемой к охране природной территории и придания статуса особо охраняемой природной территории регионального значения государственного природного заказника «Заволжский» [Электронный ресурс] // Министерство природных ресурсов и экологии Чувашской Республики. - http://minpriroda.cap. ru/action/activity/osobo-ohranyaemie-prirodnie-territoriichuvashskoj/sozdanie-osobo-ohranyaemoj-prirodnoj-territoriireg.

4. Димитриев А.В., Дубанов И.С., Егоров Л.В., Лаврентьев Н.К., Теплова Л.П. Озеро Астраханка // Особо охраняемые природные территории Чувашской Республики: мат-лы к Единому пакету кадастровых сведений. Чебоксары: Новое время, 2012. С. 11-15.

5. Димитриев А.В., Егоров Л.В., Лаврентьев Н.К., Теплова Л.П. Озеро Изъяр // Особо охраняемые природные территории Чувашской Республики: мат-лы к Единому пакету кадастровых сведений. Чебоксары: Новое время, 2012. С. 230-233.

6. Димитриев А.В., Егоров Л.В., Лаврентьев Н.К., Теплова Л.П. Озеро Светлое с прилегающими лесами // Особо охраняемые природные территории Чувашской Республики: мат-лы к Единому пакету кадастровых сведений. Чебоксары: Новое время, 2012. C. 234-237.

7. Димитриев А.В., Егоров Л.В., Лаврентьев Н.К., Теплова Л.П., Яковлев В.А. Озеро Большое Лебединое и Малое Лебединое // Особо охраняемые природные территории Чувашской Республики: мат-лы к Единому пакету кадастровых сведений. Чебоксары: Новое время, 2012. С. 225-229.

8. Синичкин Е.А., Богданов Г.А., Димитриев А.В., Семенова И.И., Омельченко П.Н. О новых и редких видах лишайников из лесных районов Заволжья Чувашской Республики // Вестник Волжского университета имени В.Н. Татищева. 2013. № 4 (14). С. 58-63.
9. Синичкин Е.А., Богданов Г.А., Димитриев А.В., Смирнова Н.В., Омельченко П.Н. К изучению лишайников государственного природного заказника «Заволжский» (Чувашская Республика) // Самарский научный вестник. 2018. Т. 7, № 4 (25). С. 108-115.

10. Семенова И.И., Акбердина Р.Х., Синичкин Е.А. Анализ лихенофлоры окрестности реки Варламовка Чувашской Республики // Научное наследие В.И. Вернадского и современные проблемы науки: сб. матлов всерос. конф. Чебоксары: Новое время, 2010. C. $85-88$.

11. Синичкин Е.А., Богданов Е.А., Омельченко П.Н. Предварительные итоги изучения лихенофлоры Чувашской Республики // Тез. докл. II (X) междунар. ботанической конф. молодых ученых в СанктПетербурге 11-16 ноября 2012 года. СПб.: СПбГЭТУ «ЛЭТИ», 2012. С. 43-44.

12. Синичкин Е.А., Богданов Г.А., Омельченко П.Н. Редкие и исчезающие лишайники Чувашской Республики, нуждающиеся в охране // Раритеты флоры Волжского бассейна: докл. участников II Российской науч. конф. Тольятти: Кассандра, 2012. С. 230-230.

13. Голубкова Н.С., Трасс Х.Х. Лишайники // Жизнь растений. Т. 3. М.: Просвещение, 1977. С. 379-470.

14. Определитель лишайников СССР: Морфология, систематика и географическое распространение. Вып. 2. Л.: Наука, 1974. 284 с.

15. Бязров Л.Г. Лишайники в экологическом мониторинге. М.: Научный мир, 2002. 336 с.

16. Закутнова В.И., Пилипенко Т.А. Мониторинг лишайников дельты Волги. Астрахань: Астраханский университет, 2004. 116 с.

17. Малышева Н.В. Лишайники Санкт-Петербурга // Труды Санкт-Петербургского общества естествоиспытателей. Сер. 3. Т. 79. СПб.: Изд-во Санкт-Петербургского университета, 2003. 100 с.

18. Малышева Н.В., Смирнов А.Г. Определитель лишайников Татарской АССР. Казань: Изд-во Казанского ун-та, 1982. 148 с.

19. Мучник Е.Э. Лихенологические исследования на территории Центрального Черноземья России (состояние вопроса) // Новости систематики низших растений. Т. 32. СПб.: Наука, 1998. С. 64-72.

20. Мучник Е.Э. Конспект лишайников степных и остепнённых местообитаний Центрального Черноземья // Новости систематики низших растений. Т. 35. СПб.: Наука, 2001. С. 183-195.

21. Пыстина Т.Н. Лихенофлора равнинной части Республики Коми (подзоны южной и средней тайги): автореф. дис. ... канд. биол. наук. Сыктывкар, 2000. 18 с. 
22. Рябкова К.А. Лишайники Урала: учеб. пособие. Свердловск: Изд-во СГПУ, 1981. 52 с.

23. Флора лишайников России: Биология, экология, разнообразие, распространение и методы изучения лишайников / отв. ред. М.П. Андреев, Д.Е. Гимельбрант. М.; СПб.: Т-во науч. изданий КМК, 2014. 392 c.

24. Макрый Т.В. Лишайники Байкальского хребта. Новосибирск: Наука. Сиб. отделение, 1990. 200 с.
25. Маевский П.Ф. Флора средней полосы европейской части России. 11-е изд. М.: Товарищество научных изданий КМК, 2014. 640 с.

26. Песенко Ю.А. Принципы и методы количественного анализа в фаунистических исследованиях. М.: Наука, 1982. 282 с.

27. Корчиков Е.С. Лишайники Самарской Луки и Красносамарского лесного массива. Самара: Издательство «Самарский университет», 2011. 320 с.

\title{
ECOLOGICAL AND SUBSTRATE CHARACTERISTICS OF LICHENOFLORA OF THE STATE NATURE RESERVE «ZAVOLZHSKY» (CHUVASH REPUBLIC)
}

(C) 2019

\author{
Sinichkin Evgeny Arkadyevich, researcher \\ Dimitriev Aleksandr Veniaminovich, candidate of biological sciences, director \\ Cheboksary Branch of the Main Botanical Garden named after N.V. Tsitsin of the Russian Academy of Sciences \\ (Cheboksary, Russian Federation)
}

Abstract. The paper provides an ecological and substrate analysis of lichens of the State Nature Reserve «Zavolzhsky» (Chuvash Republic). In the specified reserve 134 species of lichens were found. The ecological and substrate analysis showed that lichens were found on 20 substrates: on the bark of Populus tremula, Tilia cordata, Quercus robur, Acer platanoides, Betula pubescens, Padus avium, Sorbus aucuparia, Frangula alnus, Salix cinerea, S. pentandra, Alnus glutinosa, on the bark and branches of Pinus sylvestris, Picea abies, Abies sibirica, Betula pendula, on soil, on a dead organic substrate, on an anthropogenic substrate (on slate, concrete, wheel rubber). 6 main and 4 intermediate ecological groups of lichens were revealed: 1) epiphytic, growing on the bark of trees and shrubs; 2) epixylic, living on decaying wood; 3) epigeidic (ground lichens); 4) epibriophytic, living on mosses; 5) epiphytic-epixylic, growing on the bark of trees and a dead organic substrate; 6) epixylic-epigeidic, living on a dead organic substrate and soil; 7) lichens growing on the bark of trees and anthropogenic substrate; 8) epiphytic-epigeidic, growing on tree bark and soil surface 9) multisubstrate lichens that live on different substrates; 10) lichens of anthropogenic substrate. The largest number of lichens $(61,2 \%)$ belong to epiphytic, $16,5 \%$ - to epiphytic-epixylic, $5,2 \%$ - to epixylic-epigeidic, $4,5 \%$ - to epigeidic, $3,7 \%$ - to epixylic, $2,3 \%$ - to epibriophytic, $0,7 \%$ - to multisubstrate lichens, $0,7 \%$ - to epiphytic-epigeidic. 3 species of lichens were found $(2,3 \%)$ on the anthropogenic substrate. Epiphytic lichens were found on 15 forophytes. The largest number of taxa (40 species) were found on Pinus sylvestris's bark, 35 species - on Populus tremula's bark, 33 species - on Betula pendula's bark. 56 species of lichens were found on only one forophyte. The analysis of the confinement to phorophyte showed that the highest level of similarity in the species composition of lichens was found between Padus avium and Frangula alnus - 50\%, Pinus sylvestris and Picea abies - 49\%, Populus tremula and Sorbus aucuparia - 44\%, Tilia cordata and Acer platanoides - 41\%, Salix cinerea and S. pentandra - 37\%.

Keywords: lichen; state nature reserve «Zavolzhsky»; specially protected natural area; ecological and substrate analysis; ecological groups; substrate confinement; phorophytes; lichen similarity level; Chuvash Zavolzhye; Chuvash Republic.

\section{ЭКОЛОГИЧЕСКИЕ ОСОБЕННОСТИ НЕКОТОРЫХ ВИДОВ СЕМЕЙСТВА ЛАНДЫШЕВЫЕ (CONVALLARIACEAE) В УСЛОВИЯХ КИРОВСКОЙ ОБЛАСТИ}

(C) 2019

Сулейманова Венера Нуритдиновна, кандидат биологических наук, старший научный сотрудник отдела экологии и ресурсоведения растений; доцент кафедры экологии и зоологии

Егошина Татьяна Леонидовна, доктор биологических наук, профессор,

заведующий отделом экологии и ресурсоведения растений; профессор кафедры экологии и зоологии

Всероссийский научно-исследовательский институт охотничьего хозяйства и звероводства им. Б.М. Житкова (г. Киров, Российская Федерация);

Вятская государственная сельскохозяйственная академия (г. Киров, Российская Федерация)

Аннотащия. В связи с антропогенной нагрузкой на естественные местопроизрастания многих лекарственных видов растений актуальным является оценка экологических условий произрастания для изучения взаимоотношений видов и растительных сообществ. В работе представлены результаты анализа экологических условий местообитаний некоторых видов семейства Ландышевые (Convallariaceae) в Кировской области. Для выявления эколого-фитоценотической приуроченности изучаемых видов в лесных сообществах Кировской области исследовано 45 ценопопуляций (ЦП) Convallaria majalis, 10 ЦП Polygonatum odoratum и 20 ЦП Majanthemum bifolium. При анализе экологических условий местообитаний видов использовали экологические шкалы X. Элленберга. Геоботанические описания растительных сообществ проводили согласно общепринятым методам. Установлено, что амплитуды экологических пространств изученных видов в Кировской обла- 